\title{
RIWAYAT PENULIS
}

\section{Ali Sutiyo Syaifulloh}

Dosen Tetap Fakultas Hukum Universitas Tri Tunggal Surabaya. Pendidikan S1 ditempuh di Fakultas Hukum Universitas Kartini Surabaya, sedangkan S2 Magister Ilmu diselesaikan di Program Pasca Sarjana Universitas Narotama Surabaya.

\section{Fani Martiawan Kumara Putra}

Dosen Tetap Fakultas Hukum Universitas Wijaya Kusuma Surabaya. Pendidikan S1 ditempuh di Fakultas Hukum Universitas Airlangga Surabaya. Program Pasca Sarjana Ilmu Hukum S2 diselesaikan di Universitas Airlangga Surabaya. Saat ini sedang menempuh Program Doktor S3 di Universitas Airlangga Surabaya.

\section{Nyoman Nurjaya}

Dosen Tetap di Fakultas Hukum Universitas Brawijaya Malang. Pendidikan S1 Sarjana Hukum ditempuh di Fakultas Hukum Universitas Brawijaya Malang. Program Magister Hukum S2 diselesaikan di Program Pascsarjana Universitas Gadjah Mada Yogyakarta. Program Doktor S3 bidang Antropologi Hukum ditempuh di Program Pascasarjana Universitas Indonesia Jakarta.

\section{Levina Yustitianingtyas}

Dosen Tetap di Fakultas Hukum Universitas Hang Tuah Surabaya, konsentrasi di Hukum Internasional. Pendidikan S1 dan S2 Program Ilmu Hukum diselesaikan di Universitas Gadjah Mada Yogyakarta.

\section{Ronny Winarno}

Dosen Tetap di Fakultas Hukum Universitas Merdeka Pasuruan. Pendidikan S1 ditempuh di Fakultas Hukum Universitas Jember. Program Magister Ilmu Hukum S2 diselesaikan di Universitas Surabaya. Program Doktor S3 diselesaikan di Program Doktor Ilmu Hukum Pascasarjana Universitas Brawijaya Malang.

\section{Umi Enggarsasi}

Dosen Tetap di Fakultas Hukum Universitas Wijaya Kusuma Surabaya. Pendidikan S1 Ilmu Hukum dan S2 Program Magister Ilmu Hukum ditempuh di Universitas Airlangga Surabaya. Program Doktor Ilmu Hukum diselesaikan di Universitas Islam Bandung.

\section{Atet Sumanto}

Dosen Tetap di Fakultas Hukum Universitas Wijaya Kusuma Surabaya. Pendidikan S1 ditempuh di Fakultas Hukum Universitas Wijaya Kusuma Surabaya. Program Magister Hukum ditempuh di Pascasarjana Universitas Islam Kadiri Kediri. Saat ini sedang menempuh Program Doktor Ilmu Hukum diUniversitas 17 Agustus 1945 Surabaya. 


\section{PEDOMAN PENULISAN}

Jurnal Perspektif merupakan jurnal triwulanan untuk mempublikasikan hasil penelitian atau kajian konseptual tentang isu-isu hukum atau pun teori hukum yang belum dipublikasikan di media lain baik elektronik maupun media cetak. Jurnal Perspektif terbit tiga nomor dalam setahun (Januari, Mei, dan September). Jurnal ini ditujukan untuk kalangan akademisi, praktisi, penyelenggara negara, Lembaga Swadaya Masyarakat (LSM), serta pemerhati hukum. Jurnal Perspektif memiliki Nomor ISSN Cetak 14103648 dan ISSN Online 2406-7385.

Tata cara penulisan dan pengiriman naskah dalam Jurnal Perspektif, sebagai berikut:

1. Naskah yang dikirim merupakan karya ilmiah asli dan tidak mengandung unsur plagiarisme.

2. Naskah ditulis dalam Bahasa Indonesia atau Bahasa Inggris sepanjang 25-30 halaman, kertas berukuran A4, jenis huruf Times New Roman, ukuran font 12, dan spasi 1,5. Menggunakan istilah yang baku serta bahasa yang baik dan benar.

3. Naskah ditulis dalam format jurnal dengan sistem baris kredit (byline).

a. Sistematika penulisan artikel hasil penelitian mencakup: Judul Artikel, Nama Penulis, Lembaga Penulis, Alamat Lembaga Penulis, Alamat e-mail Penulis, Abstrak, Kata Kunci, Pendahuluan (berisi latar belakang masalah, permasalahan, dan metode penelitian), Pembahasan (berisi hasil penelitian, analisis dan sub-sub bahasan), Penutup (berisi kesimpulan dan saran), dan Daftar Pustaka.

b. Sedang sistematika pembagian artikel kajian konseptual mencakup: Judul Artikel, Nama Penulis, Lembaga Penulis, Alamat Lembaga Penulis, Alamat e-mail Penulis, Abstrak, Kata Kunci, Pendahuluan, Pembahasan (analisis dan sub-sub bahasan), Penutup (berisi kesimpulan dan saran), dan Daftar Pustaka.

4. Judul artikel harus spesifik dan lugas yang dirumuskan dengan maksimal 12 kata (Bahasa Indonesia), 10 kata (Bahasa Inggris), atau 90 ketuk pada papan kunci, yang menggambarkan isi artikel secara komprehensif.

5. Abstrak (Abstract) ditulis secara gamblang, utuh dan lengkap menggambarkan esensi isi keseluruhan tulisan dalam dua bahasa yaitu
Bahasa Indonesia dan Bahasa Inggris yang masing-masing satu paragraf.

6. Kata Kunci (Keywords) yang dipilih harus mencerminkan konsep yang dikandung artikel terkait sejumlah 3-5 istilah.

7. Cara pengacuan dan pengutipan menggunakan model catatan kaki (footnote).

a. Kutipan Buku: Nama Penulis, Judul Buku, Tempat Penerbitan: Nama Penerbit, Tahun Terbitan, Halaman Kutipan.

Contoh:

${ }^{1}$ Malcolm Swan, International Law, $10^{\text {th }}$ ed., Inggris, Cambridge University, 2013, h. 127.

2 Damos Dumali Agusman, Hukum Perjanjian Internasional Kajian Teori dan Praktik Indonesia, Bandung: Refika Aditama, 2010, h. 17.

b. Kutipan Jurnal: Nama Penulis, "Judul Artikel”, Nama Jurnal, Volume, Nomor, Bulan dan Tahun, Halaman Kutipan.

Contoh:

${ }^{3}$ Ria Tri Vinata, "Penentuan Batas Wilayah Laut Indonesia", Jurnal Perspektif, Volume 10, Nomor 3, Edisi Mei Tahun 2011, h. 647. ${ }^{4}$ Arief Hidayat, "Politik Hukum Konstitusi dan Fenomena Absentia Voter (Golput) Dalam Pemilu di Indonesia", Jurnal Konstitusi, Volume 1, Nomor 1, Juni 2009, h. 20.

c. Kutipan Makalah: Nama Penulis, "Judul Makalah", Nama Forum Kegiatan, Tempat Kegiatan, Tanggal Kegiatan, Halaman Kutipan.

Contoh:

${ }^{5}$ Moh. Mahfud M.D., "Separation of Powers and Independence of Constitutional Court in Indonesia", Paper Presented at The $2^{\text {nd }}$ Congress of The World Conference on Constitutional Justice, Rio de Janeiro-Brazil, 16-18 January 2011, h. 7.

d. Kutipan Internet/Media Online: Nama Penulis, "Judul Tulisan", Alamat Portal (Website/Online), Tanggal diakses/unduh. Contoh:

${ }^{6}$ Muchamad Ali Safa'at, "Militer dalam Perspektif Hukum Tata Negara", http:// anomalisemesta.blogspot.com/2007/10/ artikel_06.html, diunduh 27 Desember 2007. 
8. Daftar Pustaka memuat: Daftar Peraturan Perundang-undangan, Daftar Buku, Jurnal, Makalah/Paper/Orasi Ilmiah baik cetak maupun online yang dikutip dalam naskah, yang disusun secara alfabetis (A to Z) dengan susunan: Nama Penulis (mendahulukan nama keluarga/marga), Tahun, Judul, Tempat Penerbitan: Penerbit, dst. seperti contoh berikut ini:

a. Kutipan Buku:

Nama Penulis. Judul Buku. Tahun Terbitan. Tempat Penerbitan: Nama Penerbit.

b. Kutipan Jurnal:

Nama Penulis. "Judul Artikel”. Nama Jurnal. Volume. Nomor. Bulan dan Tahun.

Untuk Jurnal:

Nama Penulis. (Tahun Publikasi). Judul Artikel. Judul Artikel yang Periodik, Nomor Volume. Webiste http://www.someaddress. com/full/url/

Untuk Jurnal dengan DOI:

Nama Penulis. (Tahun Publikasi). Judul Artikel. Judul Jurnal, Nomor Volume,
Halaman. doi:0000000/000000000000 atau http://dx.doi.org/10.0000/0000

c. Seminar:

Nama Penulis, "Judul Makalah", Nama Forum Kegiatan, Tempat Kegiatan, Tanggal Kegiatan.

9. Naskah dalam bentuk file dokumen Microsoft Word (*.doc) dapat dikirim via e-mail ke alamat e-mail Redaksi Jurnal Perspektif: perspektif hukum@yahoo.com atau login di http://jurnalperspektif.org dengan terlebih dahulu mendaftar (register) sebagai Penulis (Author). Naskah dapat juga dikirim via pos kepada: REDAKSI JURNAL PERSPEKTIF. FAKULTAS HUKUM UNIVERSITAS WIJAYAKUSUMA SURABAYA Jl. Dukuh Kupang XXV/25 Surabaya 60225. Telp. (031) 5677577 Website: http://jurnal-perspektif. org

10. Dewan Editor menyeleksi dan mengedit naskah yang masuk tanpa mengubah substansi. Naskah yang tidak dimuat akan dikembalikan atau diberitahukan kepada penulisnya. 



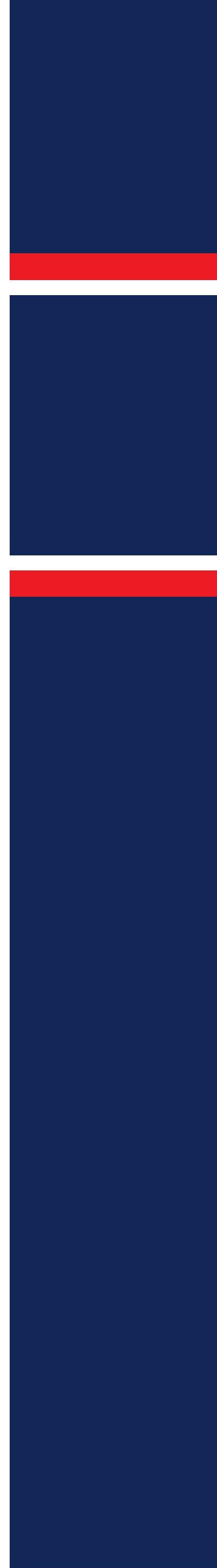